\title{
Determining the relationship between dietary iodine intake, urinary iodine excretion and thyroid functions in people with type 2 diabetes mellitus
}

Rahime Evra Karakaya

https://orcid.org/0000-0003-1368-3501

Mendane Saka ${ }^{2}$

https://orcid. org/0000-0002-5516-426X

Didem Ozdemir ${ }^{3}$

https://orcid. org/0000-0001-7826-9059

\begin{abstract}
Objective: Type 2 diabetes mellitus (T2DM) is a worldwide health problem, and medical nutrition therapy is essential for improving the quality of life of patients with type 2 diabetes. Salt restriction may lead to iodine deficiency in these patients. Moreover, type 2 diabetes can be an indirect reason for thyroid disorders. This study was conducted to determine the relationship between dietary iodine intake, urinary iodine excretion and thyroid functions in people with T2DM. Materials and methods: lodine nutritional status was determined by a one day 24-h dietary recall and food-frequency questionnaire. lodine status was detemined by urinary iodine excretion with morning urine sample. Results: lodine intake according to one day 24-h dietary recall was lower inT2DM patients [94.8 (76.0112.0) $\mu \mathrm{g}$ ] than people in control group [137.1 (123.1-165.4) $\mu \mathrm{g}$ ] $(\mathrm{p}<0.05)$. lodine intake determined by food-frequency questionnaire rich in iodine was lower in T2DM patients [93.1 (84.4-113.9) $\mu \mathrm{g}$ ] than people in control group [140.2 (125.1-166.1) $\mu \mathrm{g}](\mathrm{p}<0.05)$. Mild iodine deficiency was found in \%38.8 of diabetic and $\% 55.1$ of healthy individuals $(p<0.05)$. No significant relationship was found between urinary iodine excretion and thyroid function tests in groups $(p>0.05)$. However, the relationship between dietary iodine excretion and urinary iodine intake in the diabetic group was lower than in the control group $(p<0.05)$. Conclusion: With this respect, the results showed that while planning medical nutrition therapy for diabetic individuals, the risk of iodine deficiency should be considered. Arch Endocrinol Metab. 2020;64(4):383-9
\end{abstract}

Keywords

Type 2 diabetes mellitus; iodine; iodine deficiency; thyroid disorders

\author{
${ }^{1}$ Ankara Yildirim Beyazit University, \\ Faculty of Health Sciences, \\ Department of Nutrition and \\ Dietetics, Ankara, Turkey \\ ${ }^{2}$ Baskent University, \\ Faculty of Health Sciences, \\ Department of Nutrition and \\ Dietetics, Ankara, Turkey \\ ${ }^{3}$ Ankara Yildirim Beyazit \\ University, Faculty of Medicine, \\ Department of Endocrinology \\ and Metabolism, Ankara, Turkey
}

Correspondence to:

Rahime Evra Karakaya Ankara Yildirim Beyazit Üniversitesi Esenboğa Külliyesi Dumlupınar Mahallesi Esenboğa, Ankara, Turkey

rekarakaya@ybu.edu.tr

Received on June/12/2019 Accepted on Oct/22/2019

DOI: $10.20945 / 2359-3997000000233$

\section{INTRODUCTION}

$\mathrm{T}$ ype 2 diabetes mellitus (T2DM) is a chronic metabolic disease that requires continuous medical care in which the body can not benefit sufficiently from carbohydrates, fats and proteins due to insulin deficiency or impairment of insulin action. Nowadays diabetes has become a health problem all over the world due to its frequency and complications. While the number of people with diabetes in the world was 415 million in 2015 , it is predicted that this number will reach 642 million by 2040 with an increase of $55 \%$ (1). The main reasons for this increase are population growth, aging, and lifestyle changes brought about by urbanization, resulting in increased obesity and physical inactivity (2).

The goal of diabetes treatment is to prevent microvascular and macrovascular complications and control cardiovascular risk factors along with lowering blood glucose to normal levels. The first and main approach in all types of diabetes that should be continued during the illness is patient education, medical nutrition therapy (MNT) and exercise. MNT is the most important part of education for diabetes treatment and management (3). The goals of MNT are to provide metabolic control, prevent chronic complications of diabetes, determine the nutritional needs of the individual by taking the personal and cultural characteristics into consideration, and to achieve self-management skills in various situations (e.g. exercise, hypoglycemia, acute illness etc.) (4).

Iodine, a micronutrient, is an important component of the thyroid hormones required for the normal growth and development of the brain and nervous system and homeostasis (5). All diseases caused by inadequate 
iodine intake or impaired iodine metabolism are called "Iodine Deficiency Disorders (IDD)" (6). The optimal method to determine iodine deficiency is to assess the amount of urinary iodine. Inadequate iodine intake is usually associated with low iodine content in the soil, and therefore, low iodine content in the nutrients consumed. In addition, lower seafood consumption results in inadequate iodine intake (7). The adverse effect of iodine deficiency on the human body is the reduction of the formation of thyroid hormones. Inadequate iodine intake is the most important cause of goitre. Iodine deficiency may lead to goitre, hypothyroidism, mental retardation, infertility, lack of physical performance and increase in some types of thyroid cancer in adulthood (6).

Diabetes and thyroid diseases are endocrine diseases that interact each other (8). Studies determining the pathophysiological relationship between diabetes and thyroid function support that it is comprised of biochemical, genetic and hormonal dysfunctions $(9,10)$. T2DM patients were found to have lower urinary iodine excretion than non-T2DM patients. Also, urinary iodine was negatively associated with glucose, insulin and insulin resistance (11). Adequate iodine intake is important in these patients as in the general population.

In this study, we aimed to evaluate dietary iodine intake and urinary iodine excretion in individuals with T2DM. Also, we investigated the possible association between iodine status and thyroid functions in these patients.

\section{MATERIALS AND METHODS}

\section{Subjects}

This study was conducted with 49 patients with T2DM and 49 healthy subjects aged 18-64 years were observed in our outpatient clinic between March-June 2017. Preliminary interviews were conducted with the patients and their suitability for the study was checked. T2DM patients receiving MNT and/or oral antidiabetics were included. Diabetic macrovascular and/or microvascular complications were determined as exlusion criteria. Indviduals who were not on any diet program were included in control group. All individuals with chronic diseases such as cancer, chronic liver disease, chronic renal failure, psychological disorders, thyroid diseases were excluded. Also, pregnant-lactating women, patients who are taking thyroid medication or who took it last year, who use medicines that might affect thyroid metabolism (steroids, amiodarone, lithium, etc.), who are taking iodine-containing vitamin supplements, who took iodine-containing drug in the last 6 months, who have poor blood glucose regulation $(\mathrm{HbAlc}>$ $8 \%$, and those with iodine restriction were excluded from the study.

\section{DESIGN}

A questionnaire form consisting of three sections (sociodemographic characteristics, information about diabetes, nutritional habits) was applied to participants with face-to-face interview method. One-day $(24 \mathrm{~h})$ dietary recall was taken to assess the intake of energy and macro and micro nutrients. Nutrients were analyzed by using "Computer Aided Nutrition Program, Nutrition Package Information Systems Program (BeBiS)" developed for Turkey (12). Turkomp (13) and BEBIS databases were used to determine the iodine content of foods. In addition, a form consisting of information about iodine intake (family history of goiter disease, iodised salt consumption status, storage conditions, duration and amount of iodised salt intake and etc.), frequency of consumption of 14 iodine rich foods (milk, yoghurt, cheese, egg, offal, oily fish, shellfish, other seafood, green leafy vegetables, other vegetables, potato, citrus, other fruits) and 3 goitrogenic foods (radish, turnip juice, cabbage) was applied. Anthropometric measurements of individuals (body weight, height, waist and hip circumference) were taken by a trained researcher. Body mass index (BMI) was calculated by the formula [( body weight $(\mathrm{kg}) /\left(\right.$ height $\left.\left.(\mathrm{m})^{2}\right)\right]$ evaluated according to WHO criteria (14).

\section{Laboratory assays}

Fasting blood glucose (FBG), glycosylated hemoglobin (HBAlc) and insulin levels were measured in the blood samples taken after 12 hours of fasting. Insulin resistance (HOMA-IR) was calculated by fasting insulin $(\mu \mathrm{U} / \mathrm{mL})$ $\mathrm{x}$ fasting plasma glucose $(\mathrm{mg} / \mathrm{dL}) / 22.5$ formula (15). Thyroid functions were assessed by measuring plasma Thyrotrophin hormone (TSH), free triiodothyronine (fT3), free thyroxine (fT4), Antithyroglobulin (Anti $\mathrm{Tg}$ ), and Anti-thyroid peroxidase (Anti TPO) values. The first urine samples were taken in the morning to determine urinary iodine excretion. Iodine status was 
determined by urinary concentration and evaluated according to criteria defined by WHO (16) (Table 1).

\section{Statistical analysis}

SPSS (IBM SPSS Statistics 20) package program was used to evaluate the data obtained from study and to prepare the tables. A square analysis was performed for the qualitative variables. The indepedent sample-t test ( $\mathrm{t}$-table value) was used to compare two independent groups of parametric methods with normal values for quantitative variables, which are shown as mean \pm standard deviation $( \pm S D)$. For quantitative variables, the Mann-Whitney $\mathrm{U}$ test ( $\mathrm{Z}$ table value) was used to compare two independent groups as the values were

Table 1. lodine nutrition assessment based on median iodine concentrations

\begin{tabular}{|c|c|c|}
\hline $\begin{array}{c}\text { Urinary } \\
\text { iodine }(\mu \mathrm{g} / \mathrm{L})\end{array}$ & lodine intake & lodine status \\
\hline$<20$ & Insufficient & Severe iodine deficiency \\
\hline $20-49$ & Insufficient & Moderate iodine deficiency \\
\hline $50-99$ & Insufficient & Mild iodine deficiency \\
\hline $100-199$ & Adequate & Adequate iodine nutrition \\
\hline $200-299$ & $\begin{array}{l}\text { Above } \\
\text { requirements }\end{array}$ & $\begin{array}{c}\text { May pose a slight risk of more than } \\
\text { adequate iodine intake in these } \\
\text { populations }\end{array}$ \\
\hline$\geq 300$ & Excessive & $\begin{array}{l}\text { Risk of adverse health consequences } \\
\text { (iodine-induced hyperthyroidism, } \\
\text { autoimmune thyroid disease) }\end{array}$ \\
\hline
\end{tabular}

not normally distributed, which are shown as median [Q1-Q3]. The correlation of two quantitative variables with normal distribution is examined by using "Pearson" and the correlation coefficient of "Spearman" is used as a result of having at least one quantitative variable with non-normal distribution. The significance level of all statistical analysis was accepted as $\mathrm{p}<0.05$ (17).

\section{RESULTS}

The median age of the diabetic patients was 56.0 (53.0-61.0) years and higher than the control group [50.0 (49.0-55.0)] $(\mathrm{p}<0.05)$. The mean duration of diabetes was $8.86 \pm 7.32$ years. $12.2 \%$ diabetic patients received only MNT, and $87.8 \%$ received MNT and oral antidiabetic treatment. Prevalence of subjects making regular physical activity was higher in diabetic group compared to healthy group ( $55.1 \%$ vs. $32.7 \%, \mathrm{p}<0.05)$ (unshown data).

Median BMI was significantly higher in diabetic group $[30.7(26.6-34.9)]$ than control group 27.4 (24.4-31.9) $(\mathrm{p}=0.011)$. Biochemical parameters of the individuals demonstrated that the diabetic group had a significantly higher FBG value than the control group $(\mathrm{p}=0.001)$. In addition, diabetic patients' HbAlc and HOMA-IR levels were significantly higher than control group $(\mathrm{p}<0.001$ for each). There was no significant relationship between urinary iodine and plasma TSH,

Table 2. Mean \pm SD and median [Q1-Q3] values of individuals' BMl values and biochemical findings

\begin{tabular}{|c|c|c|c|c|c|c|c|c|c|}
\hline & \multicolumn{2}{|c|}{ Women } & \multirow{3}{*}{ p } & \multicolumn{2}{|c|}{ Men } & \multirow{3}{*}{$\mathbf{p}$} & \multicolumn{2}{|c|}{ All cases } & \multirow{3}{*}{$\mathbf{p}$} \\
\hline & $\begin{array}{c}\text { Diabetic } \\
\text { group (n: 28) }\end{array}$ & $\begin{array}{c}\text { Control group } \\
\text { (n: 31) }\end{array}$ & & $\begin{array}{c}\text { Diabetic } \\
\text { group (n: 21) }\end{array}$ & $\begin{array}{l}\text { Control group } \\
\text { (n: 18) }\end{array}$ & & $\begin{array}{l}\text { Diabetic group } \\
\text { (n: 49) }\end{array}$ & $\begin{array}{l}\text { Control group } \\
\text { (n: 49) }\end{array}$ & \\
\hline & $\overline{\mathbf{x}} \pm$ SS/Median & $\overline{\mathbf{x}} \pm$ SS/Median & & $\overline{\mathbf{x}} \pm$ SS/Median & $\overline{\mathbf{x}} \pm$ SS/Median & & $\overline{\mathbf{x}} \pm$ SS/Median & $\overline{\mathbf{x}} \pm$ SS/Median & \\
\hline $\mathrm{BMl}, \mathrm{kg} / \mathrm{m}^{2}$ & $\begin{array}{c}34.0 \\
{[28.1-35.7]}\end{array}$ & $\begin{array}{c}30.0 \\
{[25.4-34.2]}\end{array}$ & 0.040 & $28.74 \pm 3.54$ & $26.10 \pm 3.64$ & 0.028 & $\begin{array}{c}30.7 \\
{[26.6-34.9]}\end{array}$ & $\begin{array}{c}27.4 \\
{[24.4-31.9]}\end{array}$ & 0.011 \\
\hline $\mathrm{FBG}, \mathrm{mg} / \mathrm{dL}$ & $\begin{array}{c}134.0 \\
{[119.0-149.3]}\end{array}$ & $\begin{array}{c}94.0 \\
{[83.0-98.0]}\end{array}$ & 0.000 & $139.14 \pm 28.95$ & $92.44 \pm 7.01$ & 0.000 & $\begin{array}{c}134.0 \\
{[118.5-150.5]}\end{array}$ & $\begin{array}{c}94.0 \\
{[84.5-98.0]}\end{array}$ & 0.000 \\
\hline $\mathrm{HbA1c}, \%$ & $7.2[6.6-7.4]$ & $5.4[5.1-5.6]$ & 0.000 & $7.04 \pm 0.80$ & $5.31 \pm 0.28$ & 0.000 & $7.2[6.5-7.5]$ & $5.4[5.2-5.6]$ & 0.000 \\
\hline HOMA-IR, mmol/L & $3.7[2.8-5.6]$ & $1.8[1.4-2.1]$ & 0.000 & 3.3 [2.9-4.5] & 1.4 [1.5-2.1] & 0.000 & $3.5[2.8-5.2]$ & $1.8[1.4-2.1]$ & 0.000 \\
\hline $\mathrm{TSH}, \mathrm{mlU} / \mathrm{mL}$ & $1.8[1.2-2.8]$ & $1.8[1.5-3.0]$ & 0.590 & $1.37 \pm 0.62$ & $1.39 \pm 0.53$ & 0.898 & $1.5[0.9-2.1]$ & $1.7[1.3-2.3]$ & 0.453 \\
\hline $\mathrm{fT} 3, \mathrm{pg} / \mathrm{mL}$ & $2.84 \pm 0.28$ & $2.94 \pm 0.45$ & 0.316 & $3.20 \pm 0.31$ & $3.29 \pm 0.34$ & 0.410 & $2.99 \pm 0.34$ & $3.07 \pm 0.44$ & 0.362 \\
\hline $\mathrm{fT} 4, \mathrm{ng} / \mathrm{mL}$ & $1.31 \pm 0.18$ & $1.24 \pm 0.22$ & 0.208 & $1.29 \pm 0.14$ & $1.23 \pm 0.14$ & 0.213 & $1.30 \pm 0.16$ & $1.24 \pm 0.20$ & 0.090 \\
\hline Anti-Tg, IU/mL & $\begin{array}{c}21.1 \\
{[17.4-29.3]}\end{array}$ & $\begin{array}{c}16.4 \\
{[12.4-25.2]}\end{array}$ & 0.078 & $\begin{array}{c}21.1 \\
{[16.3-28.2]}\end{array}$ & $\begin{array}{c}20.1 \\
{[16.1-23.0]}\end{array}$ & 0.406 & $21.1[17.0-28.4]$ & $\begin{array}{c}18.8 \\
{[12.5-24.7]}\end{array}$ & 0.052 \\
\hline Anti-TPO, IU/mL & $\begin{array}{c}17.6 \\
{[13.9-28.5]}\end{array}$ & $\begin{array}{c}16.1 \\
{[12.5-20.5]}\end{array}$ & 0.242 & $\begin{array}{c}15.7 \\
{[11.9-22.0]}\end{array}$ & $\begin{array}{c}14.1 \\
{[11.9-16.5]}\end{array}$ & 0.455 & $16.2[13.1-25.3]$ & $\begin{array}{c}15.4 \\
{[12.4-20.2]}\end{array}$ & 0.206 \\
\hline
\end{tabular}

BMI: body mass index; FBG: fasting blood glucose; HOMA-IR: Homeostasis Model Assessment - Insulin Resistance; TSH: thyrotrophin; fT3: free triiodothyronin; fT4: free thyroxine; Anti-Tg: antithyroglobulin; Anti-TPO: antithyroid peroxidase. 
fT3, fT4, Anti Tg and Anti TPO values in patients with diabetes and control group. Similar results were obtained when further analysis was applied for women and men.

According to $24 \mathrm{~h}$ dietary recall, dietary idoine intake was $91.8 \%$ in diabetic and $69.4 \%$ in healthy individuals $(\mathrm{p}=0.011)$ (Table 3$)$. Similarly, diabetic men had significantly higher rate of inadequate iodine intake than healthy men $(90.5 \%$ vs. $55.6 \%)(\mathrm{p}=0.013)$, while the difference in diabetic women and healthy women was not significant $(\mathrm{p}=0.100)$. The daily intake of iodine determined by food frequency questionnaire including foods rich in iodine was inadequate in $95.9 \%$ of diabetic and $61.2 \%$ of the control groups $(\mathrm{p}<0.001)$. Considering the results obtained from this questionnaire, inadequate iodine intake was higher in both diabetic women and men compared to healthy women and men, respectively $(\mathrm{p}=0.002$ and $\mathrm{p}=0.003$ respectively). In iodine status, there was a significant difference between diabetic patients and healthy controls determined by iodine excretion ( $\mathrm{p}<$ $0.001)$. The significance was also valid for women and men $(\mathrm{p}<0.001$ for each). Moderate iodine deficiency was observed in $49.0 \%$ of diabetic patients whereas moderate iodine deficiency wasn't detected in control group. Mild iodine deficiency was found in $38.8 \%$ of the diabetic individuals and in $\mathbf{5 5 . 1 \%}$ of the control group. Urinary iodine excretion level was normal in $8.2 \%$ of the diabetic group and $42.9 \%$ of the control group.

A correlation analysis was made to identify the possible association between urinary iodine excretion and biochemical findings and dietary iodine intake in diabetic patients and healthy controls. There was no significant relationship between urinary iodine excretion and FBG, HbAlc, insulin, HOMA-IR, thyroid functions and thyroid autoantibodies in diabetic and healthy group (Table 4).

A positive relationship was found between urinary iodine excretion and dietary iodine intake with $24 \mathrm{~h}$ dietary recall in diabetic and control groups $(\mathrm{p}<0.001$ and $\mathrm{p}=0.001$, respectively). There was a positive relationship between urinary iodine excretion and iodine intake with food frequency form in diabetic and control groups ( $\mathrm{p}=0.001$ and $\mathrm{p}<0.001$, respectively) (Table 5). These associations were also observed when patients and control groups were subgrouped as women and men.

\section{DISCUSSION}

Metabolic control can be achieved via MNT with drug and exercise treatment in diabetic individuals. MNT is generally based on the individual's diet to reduce total

Table 3. Grouping individuals' dietary iodine intake and urinary iodine excretion according to adequate level

\begin{tabular}{|c|c|c|c|c|c|c|c|c|c|c|c|c|}
\hline & \multicolumn{4}{|c|}{ Women } & \multicolumn{4}{|c|}{ Men } & \multicolumn{4}{|c|}{ All cases } \\
\hline & \multicolumn{2}{|c|}{$\begin{array}{l}\text { Diabetic group } \\
\text { (n: 28) }\end{array}$} & \multicolumn{2}{|c|}{$\begin{array}{l}\text { Control group } \\
\text { (n: 31) }\end{array}$} & \multicolumn{2}{|c|}{$\begin{array}{l}\text { Diabetic group } \\
\text { (n: 21) }\end{array}$} & \multicolumn{2}{|c|}{$\begin{array}{l}\text { Control group } \\
\text { (n: 18) }\end{array}$} & \multicolumn{2}{|c|}{$\begin{array}{l}\text { Diabetic group } \\
\text { (n: 49) }\end{array}$} & \multicolumn{2}{|c|}{$\begin{array}{c}\text { Control group } \\
\text { (n: 49) }\end{array}$} \\
\hline & $\mathbf{n}$ & $\%$ & $\mathbf{n}$ & $\%$ & $\mathbf{n}$ & $\%$ & $\mathbf{n}$ & $\%$ & $\mathbf{n}$ & $\%$ & $\mathbf{n}$ & $\%$ \\
\hline \multicolumn{13}{|l|}{$\begin{array}{l}\text { lodine intake ( } 24 \text { h dietary } \\
\text { recall), } \mu \mathrm{g} / \mathrm{d}\end{array}$} \\
\hline Inadequate $(<150)$ & 26 & 92.9 & 24 & 77.4 & 19 & 90.5 & 10 & 55.6 & 45 & 91.8 & 34 & 69.4 \\
\hline \multirow[t]{2}{*}{ Adequate ( $\geq 150)$} & 2 & 7.1 & 7 & 22.6 & 2 & 9.5 & 8 & 44.4 & 4 & 8.2 & 15 & 30.6 \\
\hline & \multicolumn{4}{|c|}{$\chi^{2}=2.712, p=0.100$} & \multicolumn{3}{|c|}{$\chi^{2}=6.199, p=\mathbf{0 . 0 1 3}$} & & \multicolumn{4}{|c|}{$\chi^{2}=6.529, p=\mathbf{0 . 0 1 1}$} \\
\hline \multicolumn{13}{|l|}{ lodine intake (FFQ), $\mu \mathrm{g} / \mathrm{d}$} \\
\hline Inadequate $(<150)$ & 27 & 96.4 & 20 & 64.5 & 20 & 95.2 & 10 & 55.6 & 47 & 95.9 & 30 & 61.2 \\
\hline \multirow[t]{2}{*}{ Adequate $(\geq 150)$} & 1 & 3.6 & 11 & 35.5 & 1 & 4.8 & 8 & 44.4 & 2 & 4.1 & 19 & 38.8 \\
\hline & \multicolumn{4}{|c|}{$\chi^{2}=9.247, p=\mathbf{0 . 0 0 2}$} & \multicolumn{3}{|c|}{$\chi^{2}=8.598, p=\mathbf{0 . 0 0 3}$} & & \multicolumn{4}{|c|}{$\chi^{2}=15.515, p=\mathbf{0 . 0 0 0}$} \\
\hline \multicolumn{13}{|c|}{ Urinary iodine excretion, $\mu \mathrm{g} / \mathrm{L}$} \\
\hline Severe iodine deficiency & 2 & 7.1 & - & - & - & - & - & - & 2 & 4.1 & - & - \\
\hline Moderate iodine deficiency & 12 & 42.9 & - & - & 12 & 57.1 & - & - & 24 & 49.0 & - & - \\
\hline Mild iodine deficiency & 10 & 35.7 & 15 & 48.4 & 9 & 42.9 & 12 & 66.7 & 19 & 38.8 & 27 & 55.1 \\
\hline Optimal & 4 & 14.3 & 15 & 48.4 & - & - & 6 & 33.3 & 4 & 8.2 & 21 & 42.9 \\
\hline \multirow[t]{2}{*}{ Above requirements } & - & - & 1 & 3.2 & - & - & - & - & - & - & 1 & 2.0 \\
\hline & \multicolumn{4}{|c|}{$\chi^{2}=22.273, p=\mathbf{0 . 0 0 0}$} & \multicolumn{4}{|c|}{$\chi^{2}=18.306, p=\mathbf{0 . 0 0 0}$} & \multicolumn{4}{|c|}{$\chi^{2}=39.951, p=\mathbf{0 . 0 0 0}$} \\
\hline
\end{tabular}

FFQ: food frequency questionnaire. 
Table 4. Relationship between urinary iodine excretion and biochemical findings

\begin{tabular}{|c|c|c|c|c|c|c|c|c|c|c|c|c|}
\hline & \multicolumn{12}{|c|}{ Urinary iodine excretion, $\mu \mathrm{g} / \mathrm{L}$} \\
\hline & \multicolumn{4}{|c|}{ Women } & \multicolumn{4}{|c|}{ Men } & \multicolumn{4}{|c|}{ All cases } \\
\hline & \multicolumn{2}{|c|}{$\begin{array}{c}\text { Diabetic } \\
\text { group (n: 28) }\end{array}$} & \multicolumn{2}{|c|}{$\begin{array}{c}\text { Control } \\
\text { group (n: } 31)\end{array}$} & \multicolumn{2}{|c|}{$\begin{array}{c}\text { Diabetic } \\
\text { group (n: 21) }\end{array}$} & \multicolumn{2}{|c|}{$\begin{array}{c}\text { Control } \\
\text { group (n: 18) }\end{array}$} & \multicolumn{2}{|c|}{$\begin{array}{c}\text { Diabetic } \\
\text { group (n: 49) }\end{array}$} & \multicolumn{2}{|c|}{$\begin{array}{c}\text { Control } \\
\text { group (n: 49) }\end{array}$} \\
\hline & $\mathbf{r}$ & $\mathbf{p}$ & $\mathbf{r}$ & $\mathbf{p}$ & $\mathbf{r}$ & $\mathbf{p}$ & $\mathbf{r}$ & p & $\mathbf{r}$ & p & $\mathbf{r}$ & p \\
\hline $\mathrm{FBG}, \mathrm{mg} / \mathrm{dL}$ & 0.011 & 0.956 & -0.003 & 0.988 & 0.097 & 0.676 & 0.186 & 0.460 & 0.054 & 0.713 & 0.041 & 0.782 \\
\hline $\mathrm{HbA1c}, \%$ & -0.279 & 0.151 & 0.036 & 0.846 & 0.170 & 0.463 & 0.163 & 0.518 & -0.079 & 0.589 & 0.067 & 0.649 \\
\hline Insulin, mUU/mL & -0.137 & 0.488 & 0.071 & 0.705 & -0.279 & 0.220 & 0.088 & 0.729 & -0.142 & 0.330 & -0.005 & 0.974 \\
\hline HOMA-IR, mmol/L & -0.130 & 0.509 & 0.034 & 0.856 & -0.245 & 0.284 & 0.100 & 0.693 & -0.137 & 0.347 & 0.042 & 0.772 \\
\hline TSH, ulU/mL & -0.032 & 0.870 & -0.196 & 0.291 & -0.115 & 0.620 & 0.070 & 0.782 & 0.028 & 0.850 & -0.046 & 0.753 \\
\hline fT3, pg/mL & 0.174 & 0.375 & -0.211 & 0.254 & -0.378 & 0.091 & -0.447 & 0.063 & -0.089 & 0.541 & -0.217 & 0.134 \\
\hline $\mathrm{fT} 4, \mathrm{ng} / \mathrm{mL}$ & -0.254 & 0.192 & 0.056 & 0.766 & 0.052 & 0.822 & -0.324 & 0.190 & -0.176 & 0.227 & -0.011 & 0.939 \\
\hline Anti-Tg, IU/mL & 0.004 & 0.983 & -0.225 & 0.224 & 0.429 & 0.053 & 0.121 & 0.633 & 0.144 & 0.324 & -0.108 & 0.462 \\
\hline Anti-TPO, IU/mL & 0.012 & 0.951 & -0.132 & 0.479 & 0.368 & 0.101 & -0.071 & 0.779 & 0.184 & 0.182 & -0.003 & 0.982 \\
\hline
\end{tabular}

FBG: fasting blood glucose; HOMA-IR: Homeostasis Model Assessment - Insulin Resistance; TSH: Thyrotrophin; fT3: free triiodothyronin; fT4: free thyroxine; Anti-Tg: antithyroglobulin; Anti-TPO: antithyroid peroxidase.

Table 5. Relationship between urinary iodine excretion and dietary iodine intake

\begin{tabular}{|c|c|c|c|c|c|c|c|c|c|c|c|c|}
\hline & \multicolumn{12}{|c|}{ Urinary iodine excretion, $\mu \mathrm{g} / \mathrm{L}$} \\
\hline & \multicolumn{4}{|c|}{ Women } & \multicolumn{4}{|c|}{ Men } & \multicolumn{4}{|c|}{ All cases } \\
\hline & \multicolumn{2}{|c|}{$\begin{array}{c}\text { Diabetic } \\
\text { group (n: 28) }\end{array}$} & \multicolumn{2}{|c|}{$\begin{array}{c}\text { Control } \\
\text { group (n: } 31)\end{array}$} & \multicolumn{2}{|c|}{$\begin{array}{c}\text { Diabetic } \\
\text { group (n: 21) }\end{array}$} & \multicolumn{2}{|c|}{$\begin{array}{c}\text { Control } \\
\text { group (n: 18) }\end{array}$} & \multicolumn{2}{|c|}{$\begin{array}{c}\text { Diabetic } \\
\text { group (n: 49) }\end{array}$} & \multicolumn{2}{|c|}{$\begin{array}{c}\text { Control } \\
\text { group (n: 49) }\end{array}$} \\
\hline & $\mathbf{r}$ & $\mathbf{p}$ & $\mathbf{r}$ & $\mathbf{p}$ & $r$ & $\mathbf{p}$ & $r$ & $\mathbf{p}$ & $\mathbf{r}$ & $\mathbf{p}$ & $r$ & p \\
\hline $\begin{array}{l}\text { lodine intake ( } 24 \mathrm{~h} \\
\text { dietary recall), } \mu \mathrm{g} / \mathrm{d}\end{array}$ & 0.669 & 0.000 & 0.520 & 0.003 & 0.340 & 0.131 & 0.534 & 0.023 & 0.505 & 0.000 & 0.466 & 0.001 \\
\hline lodine intake (FFQ), $\mu \mathrm{g} / \mathrm{d}$ & 0.569 & 0.002 & 0.625 & 0.000 & 0.430 & 0.052 & 0.478 & 0.045 & 0.458 & 0.001 & 0.522 & 0.000 \\
\hline
\end{tabular}

FFQ: food frequency questionnaire.

and saturated fat, to limit the salt to reduce sodium consumption, to increase the consumption of fiber and to provide a metabolic control with moderate weight loss. Especially, the restriction on salt consumption is important because of the high blood pressure risk which is frequently encountered in these patients (18). There may be differences in daily iodine intake owing to salt restriction during the treatment. It is thought that risk of iodine deficiency is increased with salt restriction in individuals (19). At the same time, inadequate iodine intake in these individuals may cause impairment of thyroid function (17).

Iodine deficiency is a common problem in developing countries and is thought to affect about 2 billion people around the world. As a result of iodine deficiency, conditions such as goiter, hypothyroidism, impaired mental functions, decreased fertility, hyperthyroidism and cancer can be encountered in adult individuals. The most effective method for detecting the iodine status is to determine the urinary iodine excretion as it is a sensitive indicator of changes in the amount of dietary iodine intake (20). In a study with Type 1 diabetes mellitus (T1DM) and T2DM subjects, it was found that the median urinary iodine excretion of T2DM individuals was $200.0(21.0-411.0) \mu \mathrm{g} / \mathrm{L}$, and $30 \%$ of them had excessive iodine excretion. Excessive iodine excretion was thought to be associated with osmotic diuresis. In TIDM patients, the median urinary iodine excretion was determined as $150(12.0-393.0) \mu \mathrm{g} / \mathrm{L}$ and iodine deficiency was detected in $16 \%$ of them. It was thought that iodine deficiency may be associated with thyroid dysfunction due to thyroid autoimmunity, and diabetic individuals may be more susceptible to iodine deficiency disorders (8). Another study reported that low urinary iodine excretion in diabetic individuals was not a diabetic condition and was indicative of iodine deficiency due to low iodine intake in the community (21). In this study, the median urinary 
iodine excretion of diabetic subjects was significantly lower than control group $[49.6(36.3-57.0) \mu \mathrm{g} / \mathrm{L}$ vs. 91.5 (76.1-121.2) $\mu \mathrm{g} / \mathrm{L}, \mathrm{p}<0.05]$ (unshown data). According to the classification of urinary iodine excretion, it was determined that diabetic individuals had lower urinary iodine excretion than the control group in general, also mild iodine deficiency was found in control group. These results suggest that iodine deficiency is a common health problem, thus diabetic individuals may be at higher risk.

Food frequency form with iodine rich foods and 24-hour dietary recall questionnaire are applied to determine dietary iodine intake. In a study, a 53-item food frequency form containing iodine-rich foods and a 4-day dietary recall form were used to determine dietary iodine intake (22). In this study, iodine intake in diabetic patients was significantly lower than the control group according to both 24-hour dietary recall form and food frequency questionnaire rich in iodine foods. This could be explained by caloric restriction of T2DM patients. Also, salt restriction due to MNT therapy may have resulted in less iodised salt intake in these patients.

The iodine deficiency in diabetic individuals may lead to thyroid dysfunctions. In a cohort study of T2DM subjects, a positive relationship was found between urinary iodine/creatinine ratio and TSH (11). In this study, we excluded individuals with thyroid disease, and diabetic and control group had normal thyroid functions. There was no significant relationship between urinary iodine and plasma TSH, fT3, fT4, Anti Tg and Anti TPO values in patients with diabetes and control group. Also, no significant relationship between urinary iodine excretion and thyroid functions was found in groups.

Determining dietary iodine intake with dietary recall and food frequency form is an optimal method in order to assess urinary iodine excretion (23). The food frequency form only includes iodine-rich foods, suggesting that it may be better correlated with urinary iodine when daily feces excretion with $10 \mu g$ of iodine is considered (22). In this study, a positive relationship was found between urinary iodine excretion and iodine intake with 24-h dietary recall in diabetic and control groups. There was also a positive relationship between urinary iodine excretion and iodine intake with food frequency in both groups. According to these results, dietary iodine intake is considered to be a good indicator of urinary iodine excretion.

\section{Strength and limitations}

The strength of this study is that to our knowledge, this is the first study evaluating the dietary iodine intake, urinary iodine excretion and thyroid functions in people with T2DM. The limitation of this study is that the dietary iodine intake was declared by the participants which may not reflect the accurate iodine intake.

In conclusion, adequate dietary iodine intake of diabetic individuals is important for reducing iodine deficiency disorders and enhancing thyroid functions. Considering the risk of iodine deficiency while planning nutritional therapies may contribute to increasing the quality of T2DM patients' lives.

Acknowledgements: the authors thank the volunteers who participated in this trial.

Funding: this research did not receive any specific grant from funding agencies in the public, commercial, or not-for-profit sectors.

Compliance with Ethical Standards: all participants included in the study were given informed consent in accordance with the Declaration of Helsinki and the study received the approval of the Baskent University Ethics Committee for Noninterventional Clinical Trials (Project no:KAl6/377).

Disclosure: no potential conflict of interest relevant to this article was reported.

\section{REFERENCES}

1. International Diabetes Federation. Diabetes Atlas. 5th ed. 2015. Available from: http://www.idf.org/diabetesatlas. Accessed in: June 6, 2017.

2. Satman I, Omer B, Tutuncu Y, Kalaca S, Gedik S, Dinccag N, et al.; TURDEP-II Study Group. Twelve-year trends in the prevalence and risk factors of diabetes and prediabetes in Turkish adults. Eur J Epidemiol. 2013;28(2):169-80.

3. Evert $A B$, Boucher JL, Cypress M, Dunbar SA, Franz MJ, Mayer-Davis EJ, et al. Nutrition therapy recommendations for the management of adults with diabetes. Diabetes Care. 2013;36(11):3821-42.

4. Yilmaz M, Kaya A, Balci K. DiyabetTani veTedavi Rehberi 6. baski. Istanbul: Portakal Basim Matbaacilik; 2013.

5. WHO, ICCIDD, UNICEF (2001) Assessment of iodine deficiency disorders and monitoring their elimination: a guide for programme managers. Available from: http://apps.who.int/iris/ bitstream/10665/43781/1/9789241595827_eng.pdf. Accessed in: June 10, 2017.

6. Patrick L. lodine: deficiency and therapeutic considerations. Altern Med Rev. 2008;13(2):116-28.

7. Ahad F, Ganie SA. lodine, lodine metabolism and lodine deficiency disorders revisited. Indian J Endocrinol Metab. 2010;14(1):13-7.

8. Vladeva S GP, Argirova M. lodine status in patients with diabetes mellitus type 1 and type 2. Trace Elem Electroly. 2007;24(3):1435. Available from: https://doi.org/10.5414/TEP24143. Accessed in: June 10, 2017. 
9. Witting V, Bergis D, Sadet D, Badenhoop K. Thyroid disease in insulin-treated patients with type 2 diabetes: a retrospective study. Thyroid Res. 2014;7(1):2.

10. Hollowell JG, Staehling NW, Flanders WD, , Hannon WH, Gunter EW, Spencer CA, et al. Serum TSH, T(4), and thyroid antibodies in the United States population (1988 to 1994): National Health and Nutrition Examination Survey (NHANES III). J Clin Endocr Metab. 2002;87(2):489-99.

11. Al-Attas $\mathrm{O}$, Al-Daghri N, Alkharfy K, , Al-Johani NJ, Abd-Alrahman $\mathrm{SH}$, Yakout $\mathrm{SM}$, et al. Urinary iodine is associated with insulin resistance in subjects with diabetes mellitus type 2. Exp Clin Endocr Diab. 2012;120(10):618-22.

12. Ebispro for Windows, Stuttgart, Germany; Turkish version, BeBiS, version 8, (2017) Data bases: Bundeslebenmittelschlüssel, 3.01B and other sources.

13. Ulusal Gıda Kompozisyon veri tabanı-TÜRKOMP. Available from: http://www.turkomp.gov.tr/component_results/list/ID. Accessed in: June 6, 2017.

14. WHO Body Mass Index Classification. Available from: http://apps. who.int/bmi/index.jsp?introPage=intro_3.html. Accessed in: July 19, 2017.

15. Mattehews DR, Hosker JP, Rudenski AS, Naylor BA, Treacher DF, Turner RC. Homeostasis model assessment: insulin resistance and beta-cell function from fasting plasma glucose and insulin concentrations in man. Diabetologia. 1985;28(7):412-9.

16. WHO Country data on median urinary iodine and urinary iodine concentrations in school age children $<100 \mathrm{mcg} / \mathrm{l}$ 1993-2006. Available from: http://apps.who.int/iris/bitstream/ handle/10665/85972/WHO_NMH_NHD_EPG_13.1_eng.pdf;jses
sionid=FE12136804928CA54A4297D2D3DAF7C9? sequence $=1$. Accessed in: May 28, 2017.

17. Okten A, Akcay S, Cakir M, Girisken I, Kosucu P, Deger O. lodine status, thyroid function, thyroid volume and thyroid autoimmunity in patients with type 1 diabetes mellitus in an iodine-replete area. Diabetes Metab. 2006;32(4):323-9.

18. American Diabetes Association. Standards of Medical Care in Diabetes-2019. Diabetes Care. 2019;42(Suppl 1):S1-S2.

19. Tayie FA, Jourdan K. Hypertension, dietary salt restriction, and iodine deficiency among adults. Am J Hypertens. 2010;23(10):1095-102.

20. De Benoist B, Andersson M, Egli IM, Takkouche B, Allen H. lodine status worldwide: WHO global database on iodine deficiency. Available from: https://apps.who.int/iris/bitstream/ handle/10665/43010/9241592001. pdf? sequence=1\&isAllowed $=y$. Accessed in: June 25, 2017.

21. Gómez J, Maravall F, Gumà A, Abós R, Soler J, Fernández-Castañer $M$. Thyroid volume as measured by ultrasonography in patients with type 1 diabetes mellitus without thyroid dysfunction. Horm Metab Res. 2003;35(08):486-91.

22. Rasmussen LB, Ovesen L, Bülow I, Jørgensen $T$, Knudsen $\mathrm{N}$, Laurberg $\mathrm{P}$, et al. Evaluation of a semi-quantitative food frequency questionnaire to estimate iodine intake. Eur J Clin Nutr. 2001;55(4):287-92.

23. Rasmussen LB, Ovesen L, Bülow I, Jørgensen T, Knudsen N, Laurberg $\mathrm{P}$, et al. Dietary iodine intake and urinary iodine excretion in a Danish population: effect of geography, supplements and food choice. Br J Nutr. 2002;87(1):61-9. 